\title{
Identification of Child Problems \& Tracking Policies for the Protection and Fulfillment of Children's Basic Rights in South Regency as a Coastal Zone of Lampung Province
}

\author{
Noverman Duadji ${ }^{1, *}$ Novita Tresiana ${ }^{1}$
}

\author{
${ }^{1}$ Department of Public Administration, Universitas Lampung, Bandar Lampung, Indonesia \\ *Corresponding author. Email: noverman.duadji@fisip.unila.ac.id
}

\begin{abstract}
The issue of children is a global public problem and is directly related to government programs and activities. To solve children's problems requires commitment and accuracy of action with the intended targets. This research is oriented towards achieving goals, namely identifying children's problems and their causes; describes the macro framework for policies and programs to fulfil children's basic rights. Achievement of objectives requires a method; the author chooses a qualitative method. Primary data were collected through observation and interviews with selected informants, while secondary data were obtained from related documents. The research scope covered all South Lampung regencies. The analysis was carried out with a cross-matrix based on the technique of causal relationships on data to provide meaning. The results of the study show that the issue of children regarding education, health and employment which is considered by the government as the main problem is actually only symptomatic (impact) of environmental problems (poverty) of parents. The programs and activities carried out are more about relieving symptoms, while the main problems have only been partially addressed. Macro policies need to be lowered into the main program to solve poverty problems and be accompanied by affirmative programs to solve problems faced by children as symptoms. Contribution: guidelines for designing programs and activities that are relevant to the root of the problem, and placing the policy design on the main program substance and affirmative programs.
\end{abstract}

Keywords: Policies, Programs, Activities, Children's Rights, Main Programs, Affirmative Programs

\section{INTRODUCTION}

Children are divine gifts to the family and as the next generation who at certain times will become a development force towards changes in the progress of the nation. Children have an important position and are part of the potential of future human resources so that they need to get guidance and legal protection on the basic rights for wholeness, harmony and balance of physical, mental and social development. The right of children to feel safe, comfortable and prosperous is the responsibility of the family, environment and government (state). Every child has the right to live, grow and develop and participate fairly in accordance with dignity and receive protection from all forms of violence and discrimination [1]. Indonesia intends to realize a Child Friendly Indonesia and therefore supports the Convention on the Rights of the Child (KHA). On this basis, the local government has given a serious response, both at the provincial level and at the district / city government level. There are still many problems that occur to children regarding the right to health, education and other rights that need serious attention from the government. Moreover, as a research location, South Lampung Regency is one of the coastal areas in Lampung Province.

The community is of course a coastal community that has its own character that distinguishes it from non-coastal areas. Coastal communities are people who live and carry oaut related socio-economic activities and have a high enough dependence on the potential and conditions of coastal and marine resources. Regarding the problem of children, it also has differences with people who live in non-coastal areas [2].

In general, South Lampung District still finds problems related to children's rights. Some children still don't get good parenting in the family environment. There are also cases of children who have not had the opportunity for education and the opportunity to play. There are still indications of weak legal protection for children, for example related to personal identity (birth certificate). Children also often receive discriminatory treatment and acts of violence, namely an act of abuse against children by parties within or outside the environment 
where the child lives. Violence against children can be in the form of physical, emotional, verbal and sexual violence. Children also often become victims of neglect due to problems experienced by their parents [2].

There are also cases of marriage and child labor. This condition is more related to household economic problems (poverty). Sometimes there are also problems of discrimination between girls and boys. Generally, the culture of society places boys as the successor and support of the household so that they get special treatment from their parents. While girls are seen as a burden on the family, so they do not get attention, even in certain societies, girls are married off at a young age (under age) [2].

Recognition of the Convention on the Rights of the Child (CRC) is an initial form of the government's will to create a Child Friendly Indonesia. This is not enough, but it needs to be followed up with the availability of a legal basis for action and support for substantive programs, namely programs that directly address the problems faced by children, both at the central and local government levels (provincial and district / city). So the seriousness of the government can be seen from the interventions carried out in the form of policies.

This study focuses on: (a) identifying problems of children in South Lampung District; and (b) identify the legal basis for the fulfilment and protection of children's rights at the macro level as well as policies, programs and activities at the level of the South Lampung Regency Government.

\section{METHODS}

The location which is the background of the research is South Lampung Regency as part of the coastal area in Lampung Province. In general, this study aims to trace the formal legal basis for the fulfilment and protection of children's rights; identification of strategic problems of children; and analysing the suitability of program activities with children's strategic issues. To achieve the research objectives, an instrument is needed, namely a method concerning the techniques and procedures that must be followed. In accordance with the characteristics of the objectives, the researcher chose a qualitative method [3]. To obtain the necessary information (data), the research team did several things. First, conducting a survey to collect data related to children's strategic problems. Second, conducting interviews with selected informants to obtain information related to the experiences of the target group and actors in the protection and fulfilment of children's rights. Third, collecting documents related to the Child Friendly District Program (KLA). Fourth, data (information) is processed and presented in the form of narratives, tables, graphs etc. Fifth, data analysis by interpreting the data based on the theory that becomes the reference for formulating research findings.

\section{RESULT AND DISCUSSION}

\subsection{Identification of Cases and Problems of Children South Lampung District}

As a coastal area, South Lampung Regency has a character that is dominated by maritime elements. To determine strategic issues relating to the protection and fulfilment of children's rights in South Lampung Regency, the following will present demographic data describing the condition of children in this region.

Demographically, as in Table 1, the number of children in South Lampung Regency is 354,204, with details of 162,716 boys and 181,488 girls. Children in South Lampung Regency are a great potential and a successor to Indonesia's fighting ideals, especially the future of South Lampung. Children need protection - it is necessary to ensure the continuation of their full physical, mental and social growth and development. Then for children who have received education, it is illustrated in Table 2 about the following data for school children.

Comparing the data in Table 1 with Table 2, it is clear that from the total number of children of 354,204 , accumulatively only $28 \%$ or 97,785 people (44,921 boys and 52,864 girls) attend school. There are still $256,419(72 \%)$ children who have not been able to continue their schooling. Furthermore, this is also strengthened by a picture of school participation which shows a drastic decrease in APS (age group 16-18 years) in Kampung Selatan Regency. This means that there are quite a lot of children who do not continue their education until the SMA/SMK/ Madrasah Aliyah education levels.

In the Coordination Meeting for the submission of the Regional Medium Term Development Plan (RPJMD) of South Lampung Regency in the Sertung Bandiklat Kalianda Hall, it was explained that "South Lampung Human Development Index (HDI) in 2018 was $66.19 \%$ while in 2019 it was $66.96 \%$, meaning that $0.5 \%$ increase. But in terms of poverty reduction efforts there has been no decrease, so the poverty rate in South Lampung Regency is still at the position of $15 \%$, even since the tsunami disaster and the Covid-19 virus pandemic has tended to increase to $27.14 \%$ [4]. 


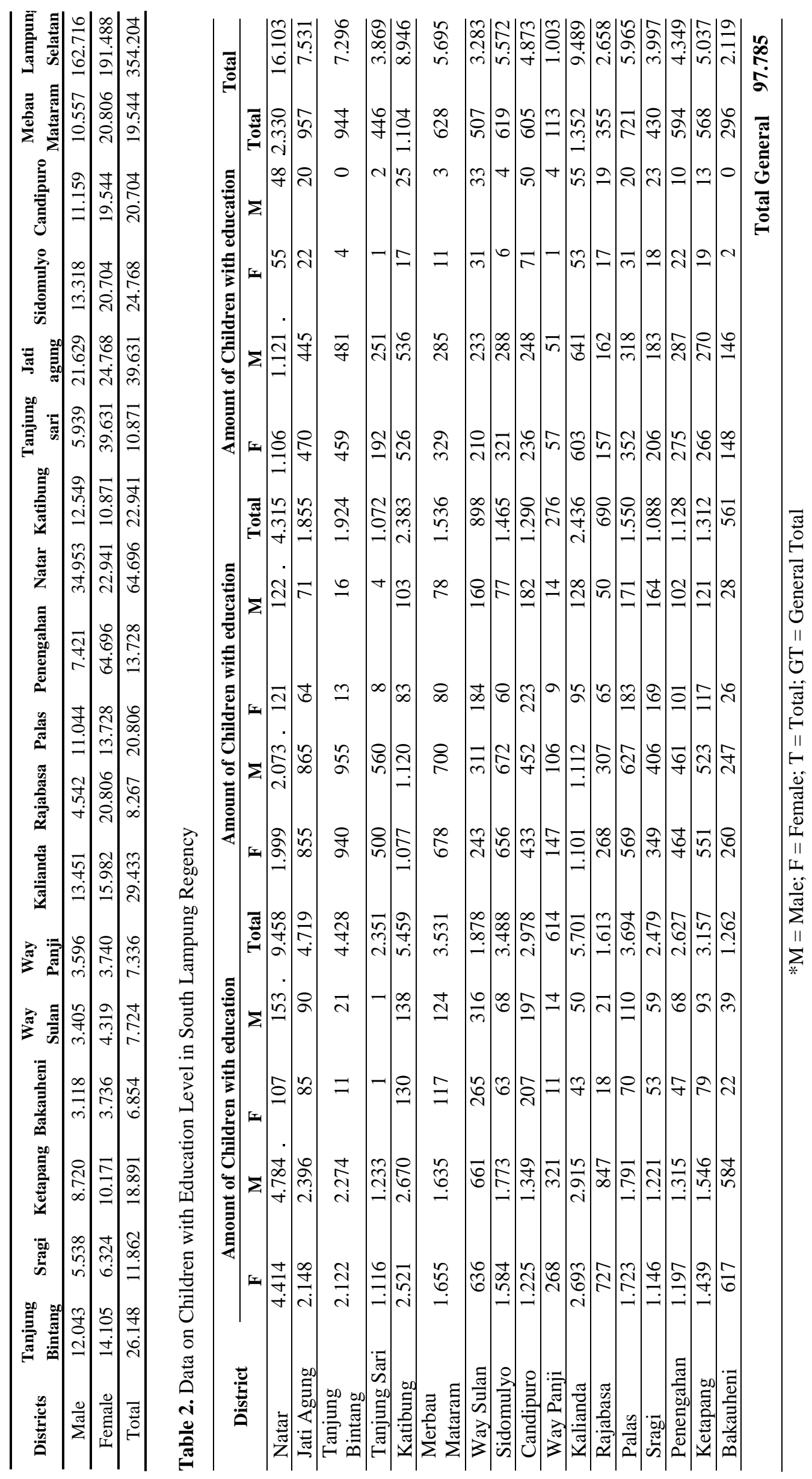


Looking at the data presented in Table 1, Table 2, Table 3 and the information recorded in the coordination meeting for the delivery of the RPJMD, it can be summarized that the first issue experienced by children in South Lampung Regency is as in Table 4.

Table 3. School Participation Rate in South Lampung Regency

\begin{tabular}{l|l}
\hline Age group & $\begin{array}{c}\text { School Participation } \\
\text { Rate }\end{array}$ \\
\hline $7-12$ & 99,41 \\
\hline $13-15$ & 92,95 \\
\hline $16-18$ & 64,49 \\
\hline
\end{tabular}

Table 4. Child Education Issues

\begin{tabular}{c|l}
\hline Causes & $\begin{array}{l}\text { Poverty of household } \\
\text { Children are involved in earning a } \\
\text { living } \\
\text { Underage marriage } \\
\text { Inequality and accessibility } \\
\text { (accessibility) of school facilities / } \\
\text { infrastructure }\end{array}$ \\
\hline Result & $\begin{array}{l}\text { High rates of children not attending } \\
\text { school \& declining school enrollment } \\
\text { rates }\end{array}$ \\
\hline
\end{tabular}

The health aspect is also an important dimension in protecting and fulfilling children's rights, and the South Lampung Regency government focuses on this issue, as evidenced by the provision of immunization to children (toddlers) as in Table 5.

Table 5. Toddlers Who Get Immunization in South Lampung Regency

\begin{tabular}{lrrrr}
\hline DISTRICTS & BCG & \multicolumn{1}{c}{ DPT } & POLIO CAMPAK \\
\hline Natar & 3.855 & 3.941 & 3.644 & 3.828 \\
Jati Agung & 2.224 & 2.212 & 2.206 & 2.216 \\
Tanjung & 1.657 & 1.662 & 1.661 & 807 \\
Bintang & & & & \\
Tanjung & 592 & 646 & 571 & 590 \\
Sari & & & & \\
Katibung & 1.371 & 1.437 & 1.291 & 1.336 \\
Merbau & 1.137 & 1.129 & 1.133 & 1.115 \\
Mataram & & & & 565 \\
Way Sulan & 564 & 556 & 552 & 514 \\
Sidomulyo & 1.426 & 1.448 & 1.375 & 1.314 \\
Candipuro & 1.055 & 1.030 & 983 & 994 \\
Way Panji & 383 & 374 & 375 & 355 \\
Kalianda & 1.757 & 1.723 & 1.663 & 1.750 \\
Rajabasa & 594 & 483 & 479 & 478 \\
Palas & 1.259 & 1.242 & 1.239 & 1.235 \\
Sragi & 748 & 732 & 731 & 733 \\
Penengahan & 782 & 803 & 809 & 780 \\
Ketapang & 962 & 1.088 & 901 & 922 \\
Bakauheni & 497 & 498 & 479 & 482 \\
\hline & & & &
\end{tabular}

\begin{tabular}{lllll}
\hline $\begin{array}{l}\text { Lampung } \\
\text { Selatan }\end{array}$ & 20.773 & 21.004 & 20.092 & 19.509 \\
\hline
\end{tabular}

The report from the South Lampung District Health Office states that through posyandu and puskesmas that are scattered in the working area, immunization for 4 types of vaccines recommended by the government has been carried out in all districts and has reached the target of $97 \%$, leaving $3 \%$ unreached. The government's alertness is better and there is an increase in public awareness compared to the previous period. This means that the fulfilment of children's health rights to get immunization (vaccines) has been carried out.

Nationally, something that needs special attention regarding children is the issue of stunting. It was reported that the prevalence of stunting in the $0-59$ month age group in Lampung Province was at $31.6 \%$, which indicates a category of serious public health problems. Of the 15 districts / cities in Lampung Province, there are 2 districts with a prevalence below the provincial prevalence or as districts with serious public health problems, namely South Lampung Regency (30.3\%) and Way Kanan Regency (30.7\%).

Table 6. Child Health Issues

\begin{tabular}{l|l}
\hline Causes & $\begin{array}{l}\text { Family poverty } \\
\text { Lack of public understanding \& } \\
\text { knowledge } \\
\text { Malnutrition }\end{array}$ \\
\hline Result & Prevalence of stunting \\
\hline
\end{tabular}

South Lampung Regency as a coastal area. It can be seen that the composition of the work of the people is $94 \%$ distributed into the agricultural, plantation, livestock, fishery and trade sectors; either as owners, cultivators or labourers. This condition reflects the atmosphere and character of life of rural communities in general.

In the 2019 national ranking, in real terms Lampung Province occupies the third position of the poorest provinces on the island of Sumatra after Aceh and Bengkulu. There was an increase in the number of poor people by $5.1 \%$, so that the poverty rate in this province was $23.11 \%$. As part of Lampung Province, the poverty rate in South Lampung Regency is $27.14 \%$. More interestingly, South Lampung Regency (27.14\%) exceeds the Lampung Province poverty rate $(23.11 \%)$ and the national poverty rate poverty rate $(11.47 \%)$ [5]. This means that in addition to contributing to the increase in the poverty rate in Lampung Province, in real terms the people of South Lampung Regency are still experiencing poverty problems. 
Data from the Manpower \& Transmigration Office of South Lampung Regency recorded that from a cumulative 354,204 children in South Regency, among children aged 10-18 years, there were a total of 25,401 children $(7.17 \%)$ who became child labourers and were distributed into the work sector as in Table 7.

Table 7. Amount and Percentage of Child Labourers aged 10-18 Years by Employment in South Lampung Regency

\begin{tabular}{|c|c|c|c|}
\hline No & Jobs & Amount & $\%$ \\
\hline 1 & $\begin{array}{l}\text { Agriculture } \\
\text { (plantation, fishery, } \\
\text { livestock) }\end{array}$ & 24.440 & 96,22 \\
\hline 2 & Mining & 3 & 0,012 \\
\hline 3 & Industries & 1 & 0,004 \\
\hline 4 & Electricity and gas & 25 & 0,098 \\
\hline 5 & Buildings & 389 & 1,53 \\
\hline 6 & Trading & 230 & 0,91 \\
\hline 7 & Transport and & & \\
\hline & Communication & 267 & 1,05 \\
\hline 8 & Finance & 0 & 0 \\
\hline 9 & Services & 1 & 0,004 \\
\hline & Total & 25.401 & 100 \\
\hline
\end{tabular}

Children (aged 0-18 years) are assets of human resources and the nation's future generation. At this age, the protection and fulfilment of the basic rights of children become the collective responsibility (parents, society and the state). Although there have been many policies at the national level and at the local (regional) level to improve the quality of life for children, it seems that they are not enough.

Observing the description and data, the phenomenon shows that the conditions of poverty plagued by most families (households) in South Lampung Regency cause child labour, whether involved in making a living in the main family work sector or employed by other parties. This condition is in line with what the ILO stated [6] in Papua, especially in poor families, there is an assumption that children have high economic value, so that many children are involved in child labour".

The results of the following interviews also show the same thing.

Interview with informant 1

"as parents, nurturing, fostering and meeting the needs of children is certainly our obligation. But with poor conditions like this, let alone fulfilling needs and providing facilities to children, it is difficult for us to do it for daily family needs alone. The family must stay alive for whatever reason. Life goes on, even eating can't be stopped. Children are our next generation and also an asset to us. Without being asked, parents are sure to provide everything their children ask for as long as they can. Make a will but it is the circumstances that make our children like this. Our children cannot continue with higher education, junior high school level is already good. Because we cannot afford to pay for our children's further studies, while we have to work in the fields and in the garden. Instead of letting them live alone at home, or hanging around not knowing where their place is, children who are 10 years old can help their parents look after their younger siblings, help their mothers cook, clean the fields, gardens and harvest activities".

Interview with informant 2

"Our unlucky family. It is still difficult for the family to meet their daily needs. Especially like me, who works as a labourer to cultivate and harvest agricultural land. Work is erratic and sometimes always changes according to other people's requests. Never mind thinking about the future of children and children's schools; It is still difficult for me to fulfil clothing, food and housing for my family. I take my children to work to earn a living".

If we look closely, the issue of child labour is also a problem faced in South Lampung Regency as shown in Table 8.

Table 8. Child Labour Issues.

\begin{tabular}{ll}
\hline Causes & Poverty of household \\
Result & Height of child labour \\
\hline
\end{tabular}

\subsection{Macro Policy of Protection and Fulfilment of Children's Rights}

The government's support for the protection and fulfilment of children's rights is reflected in the actions taken. Public policy is a 'decision as a basis for government action to allocate values and resources to target groups in order to solve problems that occur, meet needs and improve conditions for the better. The action includes programs, techniques or ways and activities carried out ' [7].

The issue of children's rights at the international level is covered by the Convention on the Rights of the Child (KHA) since November 20, 1989 which defines: "declaring to respect and guarantee the rights of every child without discrimination in any form regardless of race, color, sex, language, religion, political beliefs and other opinions, nationality, ethnic or social origin, wealth, disability, 
birth or other position of the child or the child's parents or legal guardians"

As a follow-up to the CRC, the UN general assembly on 20 November 1989 approved the concept of "World Fit For Children". The idea of a world worthy of children. The Millennium Summit also designed the Millennium Development Goals (MDGs) which substantively affirmed children's rights. Therefore, children are the next generation who will determine the world order of life in the future, so that children's problems are not only the responsibility of parents, families, communities, but become the world's attention. All states and peoples need to fully and seriously concentrate on creating a world order that provides protection and fulfilment of children's rights [8].

Indonesia is an inseparable part of international interaction and one of the members of the United Nations and is driven by a strong desire to realize a Child-Friendly Indonesia (ILA), so the right steps are to provide support for the CRC and the Government also directly ratifies Presidential Decree No. 36/1990 dated 25 August 1990. Since the Presidential Decree was signed, Indonesia has been bound by the provisions of the CRC. The next step is the enactment of Law Number 23 of 2002 concerning Child Protection on October 22, 2002 and substantively strengthening children's rights as stipulated in the Convention on the Rights of the Child. Several laws and regulations related to the protection and fulfilment of children's rights: (a) Law Number 39 of 1999 concerning Human Rights; (b) Law Number 23 Year 2002 concerning Child Protection; (c) Government Regulation Number 38 of 2007 concerning the Sharing of Government Affairs between the Government, Provincial Government and District / City Government; (d) Presidential Regulation Number 7 of 2005 concerning RPJMN; (e) Presidential Decree Number 36 of 1990 concerning Ratification of the CRC; (f) Ministerial Regulation PP No. 3/2008 concerning Guidelines for the Implementation of Child Protection; and (g) Regulation of the Minister of Government Regulation Number 02 of 2009 concerning Policies for Child-Friendly Districts / Cities [9].

Institutionally, through the Ministry of Women's Empowerment and Child Protection, the Minister of PPPA Regulation No. 11 of 2011 on the Policy for the Development of a Child Friendly District / City (KLA) was issued. KLA is a district / city that has a child rights-based development system through the integration of commitments and resources from the government, society and the business world that are planned in a comprehensive and sustainable manner in policies, programs and activities to ensure the fulfilment of children's rights. On this side, it appears that the government is really serious about protecting and fulfilling children's rights. Then it was further strengthened by the PPPA Ministerial Regulation Number 13 Year 2010 concerning Technical Guidelines for District/City Eligibility for Children in Villages / Kelurahan with the coverage of: a) Preparation; (b) Planning; (c) Implementation; and (d) Development.

The international community focuses on child issues, and the issuance of various types of national policy products proves that the Indonesian Government is also serious in responding to issues of protection and fulfilment of children's basic rights in this country. [7], [10].

Regarding the conditions and problems faced by children, as a form of commitment and concern, the local government also issued similar policy products as derivatives of central government macro policies into a more operational form in accordance with the conditions of each region.

For this reason, the South Lampung Regency Government has made and approved several policies (programs) as a response to solving problems faced by children in the region. First, the Regional Regulation of South Lampung Regency Number 4 of 2015 concerning the Implementation of Child Protection in South Lampung Regency to promote the Child Friendly Village program with a local designation known as the 'Child-Friendly Pekon Program' (PLA Program). Second, the Decree of the South Lampung Regent No: B / 261/IV.05 / HK / 2016 concerning the Determination of the Management of the South Lampung Regency Children's Forum for the Period of 2019 - 2021.

Third, the South Lampung Regent Regulation No 53 of 2017 concerning Library Transformation in South Lampung. Fourth, the Regional Regulation of South Lampung Regency No. 3 of 2018 concerning Non-Smoking Areas. Fifth, Regional Regulation of South Lampung Regency No. 3 of 2018 concerning No-Smoking Areas. Sixth, South Lampung Regent Regulation Number 10 of 2019 concerning Stunting Reduction. Seventh, South Lampung Regent Decree Number 216 of 2019 concerning the Formation of a Team for the Acceleration of Stunting Reduction.

Some of these policy products, normatively, illustrate that they already have a step forward and at the same time serve as a formal legal basis and guidelines for actions by the South Lampung Regency Government to be more operational and substantive to solve children's problems. If so, the important point is what programs and activities the government should carry out to solve children's problems? 
Said by Wiliam Dunn in the Duadji \& Tresiana version [10], [11], "To solve the problems faced, the program design and activities to be carried out must touch and go directly to the root of the problem that is the cause. Policy actors, both formatters and parties who will be involved in implementing programs and activities, must be able to find the main problems. The main problem is the source or root that causes the occurrence or root of the problem, not the symptoms that arise. Meanwhile, in dealing with problems, policy actors must carry out two (technical) steps simultaneously, namely: (a) adjusting the design of programs and activities to address the main problem known as the main program; and (b) designing programs and activities related to the handling of emergent symptoms called the sporting or affirmative program.

In line with the above explanation, policy actors and parties involved need to have a 'science and knowledge of policy'. The design of policies, programs and activities that will be carried out by the government to solve problems requires or is based on data. The problem inventory as outlined in the Problem Inventory List (DIM) must be available and upgraded at any time. This means that without the support of data, policies, programs and activities that will be carried out will be useless, like people who enter the forest aimlessly. Or like walking without a compass, you will get lost. Or like a doctor who only knows the symptoms that cause a disease without recognizing and knowing what kind of disease, then the medicine that is given will only be able to eliminate the symptoms in the patient, while the disease does not go away. [12], [13].

Random sampling of 100 children with problems shows that they come from poor families (households). Field investigations by the author team not only targeted formal data on related agencies in South Lampung Regency, but also visited several child activists and activists, namely the Mother and Child Protection Committee (KPAI) Lampung Province Representatives, NGO DAMAR, LMS LADA and members of activists and community groups who are members of the forum established by the South Lampung Regency Government, namely PATBM (Community-Based Integrated Child Protection) [14].

Table 9. Issue Issues of Children Receiving Assistance**

\begin{tabular}{cccc}
\hline $\begin{array}{c}\text { Types of } \\
\text { Child Cases } \\
\text { handled }\end{array}$ & $\begin{array}{c}\text { Number of } \\
\text { Cases } \\
\text { (Children) } \\
\text { handled }\end{array}$ & $\begin{array}{c}\text { Family's } \\
\text { background }\end{array}$ & $\begin{array}{c}\text { Companion } \\
\text { Institution }\end{array}$ \\
\hline & $\begin{array}{c}14 \text { children } \\
\text { (students) }\end{array}$ & $\begin{array}{c}\text { Poor } \\
\text { household }\end{array}$ & KPAI \\
& LADA
\end{tabular}

\begin{tabular}{|c|c|c|c|}
\hline Child & & & DAMAR \\
\hline sexual & & & Dinas \\
\hline abuse & & & PPPA \\
\hline cases & & & Lamsel \\
\hline & & & LADA \\
\hline & & & DAMAR \\
\hline Child labor & & & Dinas \\
\hline cases & 2 children & rool & PPPA \\
\hline & & & Lamsel \\
\hline & & & Disnaker \\
\hline & & & Lamsel \\
\hline Child & & Poor & $\begin{array}{l}\text { KPAI } \\
\text { LADA }\end{array}$ \\
\hline neglect & 11 children & household & DAMAR \\
\hline cases & & divorce & Dinas \\
\hline Total & 27 & & \\
\hline
\end{tabular}

** there is no data on the number of factual cases \& the exact number of children, what has been collected is the number handled (because there were reports and asked for assistance)

So the problem of children, apart from the problems raised by the South Lampung Regency Government, there were also other problems. As seen in Table 9, the Team succeeded in gathering 27 children who experienced problems, namely:

(a) 14 children experienced cases of sexual harassment at school by unscrupulous teachers;

(b) 2 children affected by the problem of unpaid child labor; and (c) 11 children experienced neglect due to poverty and parental divorce. These cases and problems only come from data on the number of problems that have received assistance and have been successfully resolved. While exact data on the factual figures of children's problems based on similar incidents and other cases have not been recorded. And it is possible that there is a tendency to the iceberg phenomenon.

Furthermore, responding to a more specific case of children [15], namely the problem of child labour, from some of the results of its research in several countries and regions in Indonesia, the ILO stated that "child labour and poverty are two inseparable things, but they are related to one another.

Child labour problems have a relationship with poverty". The same thing was conveyed by Rocky R.J. Akarro and Nathan Anthon Mtweve [16] stated that poverty is the main cause of child labour. When compared to families with better economic conditions, poor households have a tendency to send their children to the labour market or involve children in their work.

Other factors that were also examined were gender, gender, head of the family, and the number 
of family members which significantly influence the creation of child labour".

In 3 coastal village areas of South Lampung Regency, the results of observations and interviews with Head of Household informants who involve children in their work illustrate similar things.

\section{Interview with informant 1}

"I work as a boat boy (the term fisherman boat worker). I have 5 children, ranging in age from 6 to 14 years. I have been working on this job since I was not married. Only graduated from elementary school from a poor family. Yes, I can only do this kind of modelling job. My children all go to school. 4 people have graduated from elementary school and helped me and my wife's work. Another one of my children is still in "SD" school at his grandmother's place and he also lives there, with my grandmother. Please understand that the names are difficult people. Me, my wife and 4 other children are busy working".

\section{Interview with informant 2}

"I have 3 children and all have graduated from elementary school. There is a desire to continue children's schooling, but my condition is like this, a small person like this, making the children unable to continue their schooling. I entrusted one child to my younger sibling's family in Java. My younger sibling is more capable and at least can reduce the burden and financial problems of my family. Two other children are mine, helping their mother as odd jobs. Sometimes they are called by the neighbours to be stepping stones, washing clothes scrubbers, cleaning the garden and ........

Anyway what people have to offer. The important thing is to get a daily wage to help with his mother's shopping costs".

Taking into account the information from the two interviews above, there are trends that can be revealed in it. Poor households (families) perceive that conditions of poverty compel them: (a) to involve children in the child labour market, both in terms of helping the parenting profession and becoming child labour on the other side; (b) cannot facilitate further and better studies for the children's future; (c) child care for family / close relatives is a strategy or effort to reduce the burden of daily living expenses.

Although the information obtained from interviews with informants only represents labour (fishermen) and the agricultural sector, it is possible that households with other professional backgrounds also occur. Furthermore, the issue of involving children into parental work or as child labourers in the labour market corresponds to [17] "child labour and poverty are siblings" inseparable "and related to one another. In some cases, child labour and poverty form links that pass on similar things to the next generation and conditions. Therefore, in addressing this problem, humanitarian activists and organizations with the concept of children declare that "child labour is a production machine for poverty and child crime". The exploitation of children into the labour market (child labour) will damage welfare and hinder children's education, development and future.

Children are the continuing resources of the world's life. This is a wise statement. If so, then it is not just the reason that children (under 18 years of age) are not able to be independent in many ways and are still very much dependent on their immediate environment, but in fact children need protection, assistance and fulfilment of their basic rights to grow. and growing. The family, community and state environment are responsible for it. Children should be free from all matters that are not directly related to their rights, namely helping their parents, earning a living and other jobs outside their own context. They are all subjects that still need freedom to explore the environment, play, learn and be creative for their future. Children are children themselves. Thus, children and their factual problems which are sometimes called the main problem are not actually a problem, but a phenomenon that appears as an impact or a product of their immediate environment.

This study points to the above explanation. In general, the data and information that have been presented illustrate that what the South Lampung Regency Government considers the 3 main problems related to the protection and fulfilment of children's basic rights (Table 4, Table 6 and Table 8), namely (a) Issues of education which is marked by the high number of children not attending school \& decreasing school participation rate; (b) Health issues characterized by malnutrition which lead to the prevalence of stunting 'and (c) Labour issues characterized by involvement of children in earning family income and high rates of child labour. By referring to the concept of Duadji \& Tresiana [12] which states that the immediate environment is the root of the problems faced by children, the following will describe a scheme about the cycle of household poverty and the problems faced by children, especially in South Lampung Regency. 


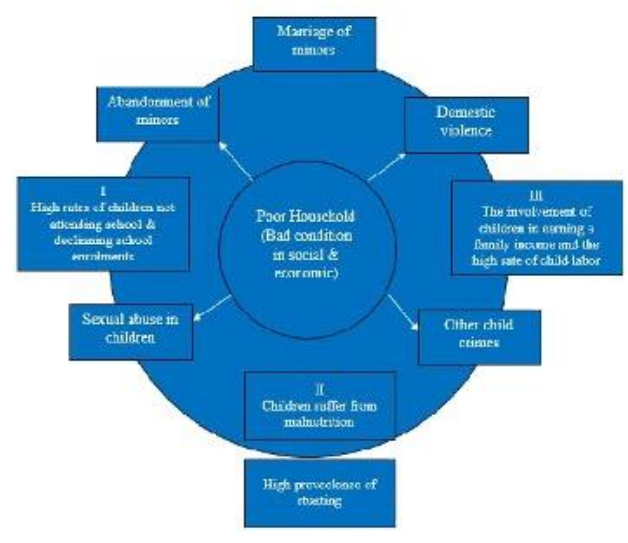

Figure 1 Poverty Cycle \& the Main Problems of Children in South Lampung Regency

Thus, to solve the problems (problems) faced by children, the South Lampung Regency Government (including policy actors and parties involved) of course needs the help of policy analysts to facilitate their work. Policy analysts have special abilities in inventorying and analysing real problems so that the design of policies, programs and activities has relevance to the root of the problem (main problems $\&$ follow-up problems) [19].

\section{Handling Child Issues}

The South Lampung Regency Government has done many things related to the handling of issues (problems) faced by children in this area. Several regulations (policies) as previously explained, have been passed. In terms of handling the protection and fulfilment of children's basic rights, the government has formed 2 direct organizational units, namely: (a) the Office of Women's Empowerment and Child Protection (PPPA), South Lampung Regency; and (b) PPPA Regional Technical Implementation Unit (UPTD).

Besides that, [19] the government views the issue of children as a shared responsibility. Handling children's issues requires joint and integrated movement of all elements. For this purpose, the government has formed an institution, namely the Community-Based Integrated Child Protection Forum (PATBM) whose members consist of elements of the government (Dinas PPPA), child activists and activists and the community (NGO) caring for children with very diverse backgrounds.

The PATBM forum, its chairperson and secretary come from members who are not from the government element, the supporting facilities for the continuity of the organization are financed by the government (both from the Regency APBD and APBN assistance from the central government). The tasks of the PATBM Forum are: (a) to collect data and analysis on child issues in the district area; (b) provide input, make considerations and propose annual programs and activities related to child issues to the PPPA Office; (c) provide counselling and education to the public regarding the protection and fulfilment of children's basic rights; (d) provide assistance and follow-up steps to child victims for problems that arise.

\section{Handling Child Education Issues}

Education is the most important thing in children's life. Education is not only intended as a need for child development, but as a determinant of the quality of the nation's human resources (state). The South Lampung Regency Government has implemented a program to meet the needs of primary and secondary education. For the cluster of children aged 4-6 years, almost every village / kelurahan (90\%) already has Early Childhood Education as a means of childcare, playgrounds and arts and cultural activities. For the 6-18 year old cluster, the government implements 12 years of compulsory education. Because this is mandatory, the government is responsible for the school's operational costs, students (students) are exempt from all forms of fees. By requiring children aged 618 years to take part in the 12 year compulsory education program, the hope is that all children at that age participate and complete.

In fact, until now, children's education is still an issue. There are $256,419(72 \%)$ children who have not been able to continue their schooling (Table 2) and the low enrolment rate (APS) in the 16-18 age group (Table 3). This means that the programs run by the government have not been successful, it still leaves problems and of course there needs to be improvements.

\section{Handling Child Health Issues}

Handling children's health is carried out through the health program with the implementing organization units being the health office, the PPPA office, the UPTD PPPA and the PATBM Forum. The handling of health issues seems to focus more on cluster children aged 0-5 years and cluster children aged 6-12 years. Children in these two clusters are still at the PAUD and SD education levels, so that in addition to Posyandu and Puskesmas, kindergarten and elementary schools are used as routine monthly places for checks, provision of additional nutrition, exclusive breastfeeding and immunization. This activity was quite successful. The prevalence of malnutrition decreased to $0.6 \%$. The trend of exclusive breastfeeding rose to $94.5 \%$. Likewise, the trend of completeness of immunization increased to $98.1 \%$. 
Behind the success, on the other hand, there are things that need special attention from the South Lampung Regency government, namely the case of children with slow growth (stunted children). In late 2019 , the prevalence of stunting in the 0-59 month age group in Lampung Province was at $31.6 \%$, while for South Lampung Regency it was $30.3 \%$. This means that for the issue of stunting, South Lampung is included in the category of areas with serious public health problems. For the handling of stunting, regulations have been issued, namely: (a) South Lampung Regent Regulation Number 10 of 2019 concerning Stunting Reduction; and (b) Decree of the South Lampung Regent Number 216 of 2019 concerning the Formation of a Team for the Acceleration of Stunting Reduction. The government has carried out: (a) area mapping and an inventory of stunting rates in all villages / kelurahan; (b) conduct health checks and provide additional nutritional supplements; (c) routine monitoring and health checks of stunting children; and (d) is preparing a follow-up program for handling children with stunting, including the budget. However, the stunting management programs and activities in 2019 have not achieved too many results.

\section{Addressing Child Labour Issues}

The data shows that rural communities with agricultural culture are still dominated by traditional patterns, conditions of economic difficulty are still dominant. There are 256,419 (72\%) children who cannot complete the 12 year compulsory education program in South Lampung and all are involved in their parents' work. The government cannot do much to deal with cases of children's involvement in their parents' activities.

Programs and activities carried out by the government are more directed at: (a) socialization in the family environment about the importance of protecting and fulfilling children's basic rights; and (b) appeals to parents to encourage their children to join the 12 year compulsory education program. However, for the salient cases shown in Table 9, the government played an active role. For the case of 2 child labourers who were not treated properly and did not get a salary, the South Lampung Regency Government has formed an integrated team consisting of the PPPA Office, Manpower Office, Social Service, UPTD PPPA, LSM LADA, LSM DAMAR, KPAI and the PATBM Forum.

This integrated team carries out investigations and negotiations with the employer who employs the child to provide all forms of compensation including salary. Matters that have been indicated as criminal acts have been resolved legally, while the children of the victims receive psychological, health and legal assistance at the social orphanage shelter as temporary housing. Children also receive skills and business training with life insurance from the government until they return to their parents and have a business.

Observing the problems faced by children, the condition of household problems and the programs and actions that have been taken by the government, in the future the model of protecting children's rights requires improvement in the governance system (governance). The issue of child problems does not run alone, but is mostly caused by problems in the immediate environment, especially the poverty conditions experienced by households. In connection with this condition, the function of protecting and fulfilling children's basic rights will be realized if the programs and activities carried out by the government are integrated for all sectors, between government organizational units and the private and community sectors. The real action that the government needs to take is to prepare program designs and activities to solve the causes of problems and resolve the effects of the problems. The government in designing actions requires data support and assistance as well as optimization of the policy analysts that have been available so far.

\section{CONCLUSION AND RECOMMENDATION}

Problems that arise regarding the protection and fulfilment of children's basic rights are not a single problem that stands alone, but is more caused by problems in the immediate environment. This requires special handling with the support of all parties (government, private sector and society). On the basis of research results, recommendations that can be submitted to improve programs and activities that have been carried out by the government so far:

- The government needs data support and policy analyst assistance

- Integration and synchronization of programs and activities by across sectors and across government organizational units with the involvement of private parties and the community.

- Prepare a more comprehensive program design and activity towards solving the cause of the problem (main program) and solving the impact of the problem as a symptom (affirmative program). 


\section{ACKNOWLEDGMENTS}

On this auspicious occasion, allow our thanks to all those who have provided support, especially to:

1. Kementrian Riset dan Teknologi/Badan Riset dan Inovasi Nasional, Deputi Bidang Penguatan Riset dan Pengembangan Republik Indonesia, melalui Skema Penelitian Kompetitif Nasional Penelitian Dasar Tahun 2020

2. Pemerintah Kabupaten Lampung Selatan Propinsi Lampung

\section{REFERENCES}

[1] Erdianti. (2019). Mewujudkan Desa Layak Anak Sebagai Bentuk Perlindungan Hukum Terhadap Anak Indonesia. Justisia Jurnal Hukum, Fakultas Hukum Muhammadiyah Malang.

[2] Duadji, N \& Tresiana, N. (2020). Laporan Hasil Penelitian. Pekon Tanggap Covid-19: Membangun Bridging Sosial Capital Perlindungan dan Pemenuhan Hak Anak: Hibah Kompetitif Penelitian Dasar Direktoral Jenderal Pendidikan Tinggi Kementerian Pendidikan dan Kebudayaan RI. Universitas Lampung.

[3] Creswell, J. W. (2007). Research Design: Qualitative, Quantitative and Mixed Method Aproaches. SAGE Publications. https://doi.org/10.4135/9781849208956

[4] Laporan RPJMD Kabupaten Lampung Selatan, 2019.

[5] BPS-Statistic Indonesia (2016), National Labor Force Survey (SAKERNAS), Jakarta

[6] Badan Pusat Statistik Kabupaten Lampung Selatan (2016) Kabupaten Lampung Selatan dalam Angka. Kalianda: BPS Kabupaten Lampung Selatan Indonesia

[7] Van W, L. (2020). A Bias Radar for Responsible Policy-Making. In A Bias Radar for Responsible Policy-Making. https://doi.org/10.1007/978-3-030-32126-0

[8] Tresiana, N, and Duadji, N. (2018). Multi Stakeholders Governance Body Model In Achieving the Excellence Public Policy. Mimbar: Jurnal Sosial dan Pembangunan 32. (2) 401-411.

[9] Duadji, N. (2013). Partisipasi publik dalam pengambilan keputusan anggaran pendapatan dan belanja daerah (APBD) Provinsi Lampung.
Jurnal Bina Praja: Journal of Home Affairs Governance, 5(3), 197-203.

[10] Dunn, W,N. (1994). Pengantar Analisis Kebijakan Publik. Yogyakarta: Gajah Mada University Press.

[11] Duadji, N. (2017). Model Percepatan Kota Layak Anak. Laporan penelitian tidak dipublikasikan. Lampung: Universitas Lampung.

[12] Tresiana, N., \& Duadji, N. (2016). Kegagalan pemaknaan "Lembaga Musawarah Perencanaan dan Pembangunan Desa" dalam mewujudkan deepening democracy. Masyarakat, Kebudayaan dan Politik, 29(4), 191-203.

[13] Duadji, N., \& Tresiana, N. (2018). Kota Layak Anak Berbasis Collaborative Governance. Sawwa: Jurnal Studi Gender, 13(1), 1-22.

[14] Kementrian Pemberdayaan Perempuan dan Perlindungan Anak Republik Indonesia. (2016). Petunjuk Pelaksanaan Industri Rumahan, Jakarta Indonesia

[15] Duadji, N., \& Tresiana, N. (2018). A participation model based on community forum as a reproductive health knowledge transaction space to increase male participation in vasectomy. Masyarakat, Kebudayaan dan Politik, 31(1), 1-13.

[16] Akarro, Rocky R.J. and Nathan Anthon Mtweve. (2011). Poverty and Its Association with Child Labor in Njombe District in Tanzania: The Case of Igima Ward. Maxwell Scientific Organization, 2011.

[17] Ortiz, Isabel et all. (2012). Child Poverty and Inequality: New Perspectives. UNICEF, Division of Policy and Practice: New York.

[18] Brown, G. (2011). Child Labor \& Educational Disadvantage - Breaking the Link, Building Opportunity. The Office of the UN Special Envoy for Global Education: London.

[19] Duadji, N \& Tresiana, N. (2019). Laporan Penelitian Tahun ke-1 "Membangun Pekon Ramah Anak Berbasis Demokrasi Deliberatif : (Menggagas Sound Governance Body dan Citizenship Education dalam Musrenbangdes), Skema Kompetitif Nasional Penelitian Dasar Dirjendikti Kemenristekdikti (tidak dipublikasikan). 